\title{
Synthesis and Evaluation of Mannitol-Based Inhibitors for Lipopolysaccharide Biosynthesis
}

\author{
Richard E. Johnsson \\ Centre for Analysis and Synthesis, Lund University, P.O. Box 124, 22100 Lund, Sweden \\ Correspondence should be addressed to Richard E. Johnsson; richard.johnsson@redglead.com
}

Received 8 November 2015; Revised 6 January 2016; Accepted 17 January 2016

Academic Editor: Patrick J. Bednarski

Copyright ( 2016 Richard E. Johnsson. This is an open access article distributed under the Creative Commons Attribution License, which permits unrestricted use, distribution, and reproduction in any medium, provided the original work is properly cited.

\begin{abstract}
Antibiotic resistance is a serious threat against humankind and the need for new therapeutics is crucial. Without working antibiotics, diseases that we thought were extinct will come back. In this paper two new mannitol bisphosphate analogs, 1,6-dideoxy1,6-diphosphoramidate mannitol and 1,6-dideoxy-1,6-dimethansulfonamide mannitol, have been synthesized and evaluated as potential inhibitors of the enzyme $\mathrm{GmhB}$ in the biosynthesis of lipopolysaccharides. 1,6-Dideoxy-1,6-diphosphoramidate mannitol showed promising result in computational docking experiments, but neither phosphate analog showed activity in the Kirby-Bauer antibiotic susceptibility test.
\end{abstract}

\section{Introduction}

Antibiotic resistant microorganisms are among the greatest threats to human health [1-3]. The number of pathogens that acquire resistance to multiple classes of antibiotics is increasing and the need to develop new classes of antibiotics aiming for new targets is fundamental for maintaining the antibiotic era $[4,5]$. There are today Gram-negative bacteria, for example, Acinetobacter baumannii that are resistant to all FDA approved drugs [6, 7]. Therefore, new molecules with new mechanisms of action are critical for our future. The major component of the outer membrane of Gram-negative bacteria is lipopolysaccharides (LPS), which are made up of a wide range of different carbohydrates. This membrane functions as a protective barrier against antibiotics and antibacterial compounds $[7,8]$.

LPS consists of three regions: lipid A, which anchors it to the outer membrane, the core region, and the $\mathrm{O}$ antigen (Figure 1). The core region is usually connected to lipid A with one or two 3-deoxy-D-manno-octulosonic acid (Kdo) residues which are linked to a second carbohydrate, L-glycero-D-manno-heptose (L,D-Hep). The minimal LPS structure required for the growth of Escherichia coli consists of lipid A linked to two Kdo units [9]. Gram-negative bacteria without access to heptose produce a heptose-free LPS. This phenotype, called the deep-rough phenotype, is a series of characteristics that collectively reflects changes in the outer membrane leading to its instability, including hypersensitivity to hydrophobic dyes, detergents, and lipophilic antibiotics $[10,11]$. Inhibition of the L,D-Hep biosynthesis pathway should hence not influence cell propagation; however, it would result in a truncated LPS that makes the bacteria vulnerable to external stresses, such as the complement system. In this way, the virulence of the bacteria rather than cell growth is targeted and the risk for development of antibiotic resistance may be reduced [12]. In complex cases with immunocompromised hosts, an LPS inhibitor could be administered as an adjuvant making a wide range of available lipophilic antibiotics effective on Gram-negative bacteria as well.

Biosynthesis of L,D-Hep has been completely elucidated in five steps involving four enzymes: GmhA, HldE, GmhB, and HldD [13]. HldE is a bifunctional enzyme that in some species has been replaced by two enzymes, HldA and HldC [14].

The enzyme GmhB is a phosphatase that catalyzes the removal of the phosphate in position C-7 of D-glycero- $\beta$-Dmanno-heptose 1,7-bisphosphate (1) (Figure 2). The protein has also shown fructose 1,6-bisphosphate (2) dephosphorylation activity, cleaving the phosphate in position C-1 [15]. 


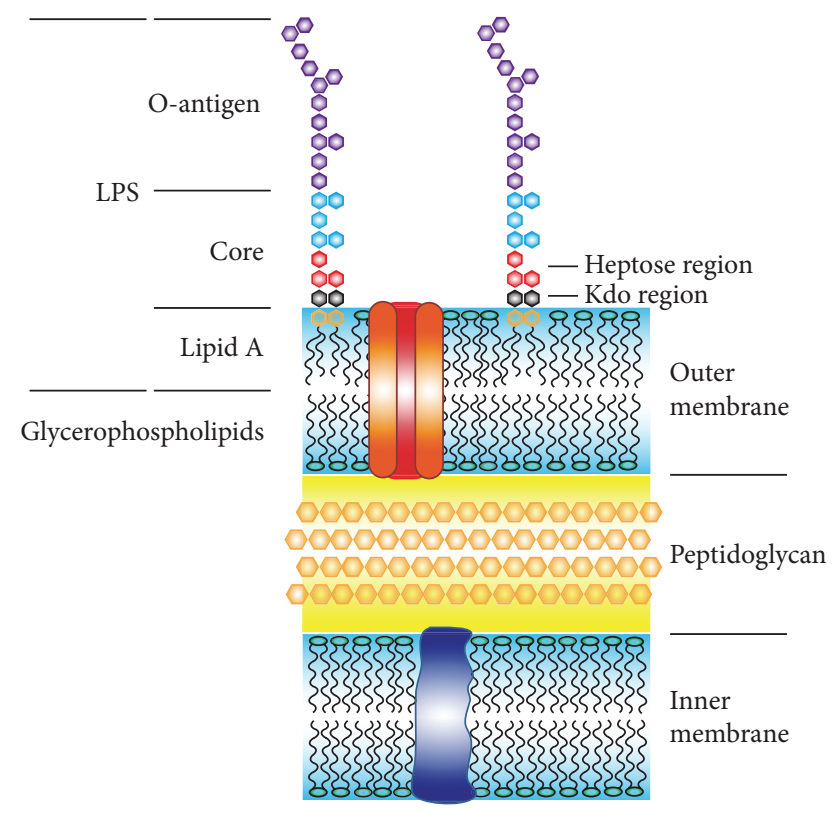

FIGURE 1: Schematic representation of a Gram-negative bacterial cell envelope (adapted from [10]).

Hexitol 1,6-bisphosphate, a mixture of glucitol and mannitol 1,6-bisphosphate, can, for example, inhibit class I and class II fructose 1,6-bisphosphate aldolase [16, 17] and fructose 1,6-bisphosphate phosphatase [18], indicating that the hexitol scaffold can be an effective scaffold to inhibit fructosebinding sites. Mabiala-Bassiloua et al. have recently showed that mannitol 1,6-bisphosphate was a better inhibitor than glucitol 1,6-bisphosphate for rabbit muscle and Helicobacter pylori aldolase [19]. To our knowledge, no inhibitors have been made towards $\mathrm{GmhB}$ and herein we present the design, synthesis, and evaluation of two different phosphate analogs. It is unknown if fructose 1,6-bisphosphate is a substrate for $\mathrm{GmhB}$ in an open linear form or in a furanose configuration and in this study we evaluated 1,6-dideoxy-1,6diphosphoramidate mannitol (3) as a charged phosphate analog and 1,6-dideoxy-1,6-dimethansulfonamide mannitol (4) as an uncharged analog to the open linear chain configuration of fructose (Figure 2).

\section{Materials and Methods}

\subsection{Synthesis Description}

General Experimental Details. NMR spectra were recorded with a Bruker Avance II $400 \mathrm{MHz}$ and ${ }^{1} \mathrm{H}$ NMR spectra were assigned using 2D methods. Chemical shifts are given in ppm downfield from the signal for $\mathrm{Me}_{4} \mathrm{Si}$, with reference to residual $\mathrm{C}_{6} \mathrm{D}_{6}\left({ }^{1} \mathrm{H}\right.$ NMR 7.16, ${ }^{13} \mathrm{C}$ NMR 128.06) or $\mathrm{D}_{2} \mathrm{O}$ $\left({ }^{1} \mathrm{H}\right.$ NMR 4.79). Reactions were monitored by TLC using alumina plates coated with silica gel and visualized either by using UV light or by charring with para-anisaldehyde. Preparative chromatography was performed with silica gel (35-70 $\mu \mathrm{m}, 60 \AA)$ or Biotage Isolera One SNAP columns. Dichloromethane and toluene were dried on an mBraun solvent dispense system, benzyl alcohol, triethylamine, and phosphorous trichloride were distilled prior to use, and pyridine (extra dry) and all other reagents were used as supplied from the manufacturer. NMR spectra of compounds $\mathbf{3}, \mathbf{4}, \mathbf{8}, \mathbf{9}$, and 10 are provided in the Supplementary Material available online at http://dx.doi.org/10.1155/2016/3475235.

1,6-Dideoxy-1,6-diphosphoramidate Mannitol (3). Compound 9 (95 mg, $0.09 \mathrm{mmol}$ ) was dissolved in EtOAc/EtOH/ $\mathrm{H}_{2} \mathrm{O}$ $(3: 5: 2,4 \mathrm{~mL})$ and $\mathrm{Pd} / \mathrm{C}(10 \%, 66 \mathrm{mg})$ was added and the mixture was hydrogenolysed at atmospheric pressure. After $4 \mathrm{~h}$ the mixture was filtered through Celite and concentrated down to approximately $1 \mathrm{~mL}, \mathrm{H}_{2} \mathrm{O}(20 \mathrm{~mL})$ was added, and the mixture was lyophilized to give $3(27 \mathrm{mg}, 89 \%) \cdot[\alpha]_{\mathrm{D}}{ }^{21}+19$ (c $\left.0.5, \mathrm{D}_{2} \mathrm{O}\right),{ }^{1} \mathrm{H} \operatorname{NMR}\left(\mathrm{D}_{2} \mathrm{O}\right): \delta 3.93$ (bs, $\left.2 \mathrm{H}\right), 3.78$ (bs, $\left.2 \mathrm{H}\right)$, 3.40 (bs, $2 \mathrm{H}), 3.06$ (bs, $2 \mathrm{H}) .{ }^{13} \mathrm{C}$ NMR $\left(\mathrm{D}_{2} \mathrm{O}\right): \delta 70.5(\mathrm{CH})$, $66.9(\mathrm{CH}), 42.5\left(\mathrm{CH}_{2}\right) .{ }^{31} \mathrm{P}$ NMR $\left(\mathrm{D}_{2} \mathrm{O}\right): \delta 0.02$. HRMS (ESI) calcd. for $\mathrm{C}_{6} \mathrm{H}_{17} \mathrm{~N}_{2} \mathrm{O}_{10} \mathrm{P}_{2}(\mathrm{M})^{-}:$339.0358, found: 339.0382.

1,6-Dideoxy-1,6-dimethansulfonamide Mannitol (4). Compound 10 (55 mg, $0.08 \mathrm{mmol}$ ) was dissolved in EtOAc/EtOH/ $\mathrm{H}_{2} \mathrm{O}(3: 5: 2,3.3 \mathrm{~mL})$ and $\mathrm{Pd} / \mathrm{C}(10 \%, 100 \mathrm{mg})$ was added and the mixture was hydrogenolysed at atmospheric pressure. After $3 \mathrm{~h} \mathrm{Pd} / \mathrm{C}(10 \%, 50 \mathrm{mg})$ was added and the mixture was hydrogenolysed at atmospheric pressure for another $18 \mathrm{~h}$. The mixture was filtered through Celite and concentrated down to approximately $1 \mathrm{~mL}, \mathrm{H}_{2} \mathrm{O}(20 \mathrm{~mL})$ was added, and the mixture was lyophilized to give $4(26 \mathrm{mg}, 99 \%)$. $[\alpha]_{\mathrm{D}}{ }^{21}+21$ (c $\left.0.4, \mathrm{D}_{2} \mathrm{O}\right),{ }^{1} \mathrm{H}$ NMR $\left(\mathrm{D}_{2} \mathrm{O}\right): \delta 3.73-3.80(\mathrm{~m}, 4 \mathrm{H}, \mathrm{H}-2, \mathrm{H}-$ 3, H-4, H-5), 3.47 (dd, 2H, J 13.5, 2.2 Hz, H-1, H-6), 3.20 (dd, 2H, J 13.5, 6.2 Hz, H-1' ${ }^{\prime}$ H-6 ${ }^{\prime}$ ), 3.09 (s, 6H, $\left.\mathrm{SCH}_{3}\right) .{ }^{13} \mathrm{C}$ $\operatorname{NMR}\left(\mathrm{D}_{2} \mathrm{O}\right): \delta 69.7,69.3,45.7,38.9$. HRMS (ESI) calcd. for $\mathrm{C}_{8} \mathrm{H}_{20} \mathrm{~N}_{2} \mathrm{O}_{8} \mathrm{~S}_{2} \mathrm{Na}(\mathrm{M}+\mathrm{Na})^{+}$: 359.0559, found: 359.0586 .

1,6-Di-O-trityl Mannitol (6). Mannitol (5) (5.05 g, $27.57 \mathrm{mmol}$ ) was coevaporated from pyridine two times and then suspended in pyridine $(95 \mathrm{~mL})$ and stirred at r.t. under nitrogen. Trityl chloride $(18.55 \mathrm{~g}, 66.55 \mathrm{mmol})$ was added followed by $\mathrm{AgNO}_{3}(12.20 \mathrm{~g}, 71.84 \mathrm{mmol})$. After $18 \mathrm{~h}$ $\mathrm{CH}_{2} \mathrm{Cl}_{2}$ was added and the mixture was washed twice with $\mathrm{NaHCO}_{3}$ (sat. aq.). The aqueous phase was extracted once with $\mathrm{CH}_{2} \mathrm{Cl}_{2}$ and the combined organic phase was dried $\left(\mathrm{MgSO}_{4}\right)$, concentrated, and coevaporated from toluene. The residue was purified by chromatography (Biotage Isolera One, SNAP 50 g, EtOAc 0-100\% in heptane; the material was split into four equal parts before chromatography and the clean fractions were pooled) to give 6 (11.17 g, 61\%). Spectral data was in agreement with previously published data [20].

2,3,4,5-Tetra-O-benzyl Mannitol (7). Compound 6 (11.06 g, $16.58 \mathrm{mmol})$ was dissolved in THF $(100 \mathrm{~mL})$ and stirred at r.t. under argon. Benzyl bromide ( $9 \mathrm{~mL}, 75.67 \mathrm{mmol}$ ) was added followed by $\mathrm{NaH}$ ( $60 \%$ suspension in oil, $4.03 \mathrm{~g}$, and $100.75 \mathrm{mmol}$ ). After $18 \mathrm{~h}$ the mixture was filtered through Celite, eluting with $\mathrm{Et}_{2} \mathrm{O}$ and then washed once with $\mathrm{H}_{2} \mathrm{O}$, dried $\left(\mathrm{MgSO}_{4}\right)$, and concentrated to give 1,6-di-O-trityl2,3,4,5-tetra-O-benzyl mannitol that was used in the next step without further purification. 1,6-Di- $O$-trityl-2,3,4,5-tetra-Obenzyl mannitol was dissolved in $\mathrm{n}-\mathrm{BuOH} / \mathrm{CH}_{2} \mathrm{Cl}_{2}(1: 1$, $230 \mathrm{~mL})$ and trifluoroacetic acid $(23 \mathrm{~mL}, 135 \mathrm{mmol})$ was 

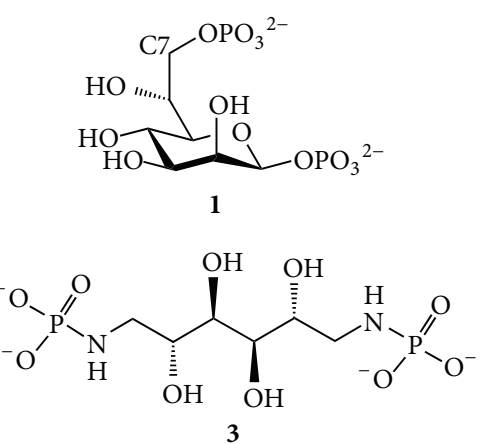
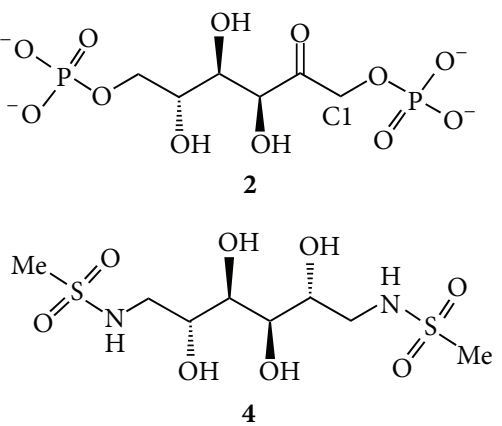

Figure 2: The enzyme GmhB is a dephosphatase that cleaves the phosphate in position C-7 of D-glycero- $\beta$-D-manno-heptose 1,7-bisphosphate (1). The enzyme also shows activity for fructose 1,6-bisphosphate (2). Compounds $\mathbf{3}$ and $\mathbf{4}$ were synthesized as analogs to compound $\mathbf{2}$.

added and the mixture was stirred at r.t. After $18 \mathrm{~h}$ the mixture was poured into $\mathrm{NaHCO}_{3}$ (sat. aq., $250 \mathrm{~mL}$ ) and stirred for $5 \mathrm{~min}$. The phases were separated and the organic phase was concentrated down. The residue was purified by chromatography $\left(\mathrm{CH}_{2} \mathrm{Cl}_{2}\right.$ followed by pentane/EtOAc $\left.1: 1\right)$ to give 7 ( $6.87 \mathrm{~g}, 76 \%$ over two steps). Spectral data was in agreement with previously published data [21].

1,6-Azido-1,6-dideoxy-2,3,4,5-tetra-O-benzyl Mannitol (8). Compound 7 (1.37 g, $2.53 \mathrm{mmol})$ was dissolved in dry pyridine $(4 \mathrm{~mL})$ and tosyl chloride $(1.22 \mathrm{~g}, 6.39 \mathrm{mmol})$ was added. The mixture was stirred for $18 \mathrm{~h}$ at r.t. under $\mathrm{N}_{2}$. $\mathrm{H}_{2} \mathrm{O}$ was added and the mixture was extracted twice with $\mathrm{CH}_{2} \mathrm{Cl}_{2}$ and the combined organic phase was washed twice with $\mathrm{H}_{2} \mathrm{O}$, dried $\left(\mathrm{MgSO}_{4}\right)$, concentrated, and coevaporated from toluene twice to give 2,3,4,5-tetra-O-benzyl-1,2-tosyl mannitol. This material was dissolved in DMSO $(3 \mathrm{~mL})$ and $\mathrm{NaN}_{3}$ (650 mg, $10.0 \mathrm{mmol}$ ) was added. The mixture was heated to $100^{\circ} \mathrm{C}$ for $18 \mathrm{~h}$ followed by $150^{\circ} \mathrm{C}$ for another $18 \mathrm{~h}$. The reaction was allowed to cool before brine was added. The mixture was extracted thrice with ether, dried $\left(\mathrm{MgSO}_{4}\right)$, concentrated, and coevaporated from toluene. The residue was purified by chromatography (Biotage Isolera One, SNAP $50 \mathrm{~g}$, EtOAc $5-95 \%$ in heptane) to give $8(774 \mathrm{mg}, 60 \%)$ as a yellow oil. IR (ATR) $v 2096 \mathrm{~cm}^{-1}\left(\mathrm{~N}_{3}\right),[\alpha]_{\mathrm{D}}{ }^{24}+100(\mathrm{c}$ 0.5 , Benzene), ${ }^{1} \mathrm{H}$ NMR $\left(\mathrm{C}_{6} \mathrm{D}_{6}\right): \delta 7.26-7.29(\mathrm{~m}, 8 \mathrm{H}, \mathrm{ArH})$, 7.14-7.19 (m, 8H, ArH), 7.06-7.12 (m, 4H, ArH), 4.64, 4.49 $\left(\mathrm{ABq}, 2 \mathrm{H}\right.$ each, $\left.J 11.5 \mathrm{~Hz}, \mathrm{PhCH}_{2}\right), 4.38,4.18(\mathrm{ABq}, 2 \mathrm{H}$ each, $J$ 11.5 Hz, $\mathrm{PhCH}_{2}$ ), 3.87-3.89 (m, 2H, H-3, H-4), 3.64-3.68 (m, 2H, H-2, H-5), 3.37, 3.25 (dABq, $2 \mathrm{H}$ each, $J$ 13.4, 5.3, $\left.2.8 \mathrm{~Hz}, \mathrm{H}-1, \mathrm{H}-1^{\prime}, \mathrm{H}-6, \mathrm{H}-6{ }^{\prime}\right) .{ }^{13} \mathrm{C} \mathrm{NMR}\left(\mathrm{C}_{6} \mathrm{D}_{6}\right): \delta 138.8$, 138.2, 128.2, 128.1, 128.00, 127.96, 79.9, 79.2, 74.6, 72.2, 50.9. HRMS (ESI) calcd. for $\mathrm{C}_{34} \mathrm{H}_{36} \mathrm{~N}_{6} \mathrm{O}_{4} \mathrm{Na}(\mathrm{M}+\mathrm{Na})^{+}$: 615.2696, found: 615.2687 .

1,6-Dideoxy-1,6-di-(di-benzyl-phosphoramidate)-2,3,4,5-tetraO-benzyl Mannitol (9). Compound 8 (94 mg, $0.16 \mathrm{mmol}$ ) was dissolved in dry toluene $(4 \mathrm{~mL})$ and stirred at r.t. under $\mathrm{N}_{2}$. Tribenzyl phosphite [22] (560 mg, $1.59 \mathrm{mmol}$ ) dissolved in dry toluene $(2 \mathrm{~mL})$ was added and the mixture was heated to $90^{\circ} \mathrm{C}$. After $18 \mathrm{~h}$ the mixture was allowed to cool down and then concentrated. The residue was purified by chromatography $\left(\mathrm{SiO}_{2}\right.$, heptane/EtOAc 1:4) to give 9
$(103 \mathrm{mg}, 61 \%)$ as a clear oil. $[\alpha]_{\mathrm{D}}{ }^{21}+19\left(\mathrm{c} 0.6, \mathrm{C}_{6} \mathrm{D}_{6}\right),{ }^{1} \mathrm{H}$ $\operatorname{NMR}\left(\mathrm{C}_{6} \mathrm{D}_{6}\right): \delta$ 6.96-7.40 $(\mathrm{m}, 40 \mathrm{H}, \mathrm{ArH}), 5.00(\mathrm{~d}, 4 \mathrm{H}, J$ $7.8 \mathrm{~Hz}, \mathrm{PhCH}_{2}$ ), 4.97 (d, $4 \mathrm{H}, J 7.9 \mathrm{~Hz}, \mathrm{PhCH}_{2}$ ), 4.79, 4.71 $\left(\mathrm{ABq}, 2 \mathrm{H}\right.$ each, $\left.J 11.3 \mathrm{~Hz}, \mathrm{PhCH}_{2}\right), 4.46,4.39(\mathrm{ABq}, 2 \mathrm{H}$ each, J $\left.11.6 \mathrm{~Hz}, \mathrm{PhCH}_{2}\right), 4.00-4.04$ (m, 2H, H-3, H-4), 3.82-3.87 (m, 2H, H-2, H-5), 3.38-3.47 (m, 4H, H-1, H-1', H-6, H-6' ), 3.28-3.37 (m, 2H, NH). ${ }^{13} \mathrm{C}$ NMR $\left(\mathrm{C}_{6} \mathrm{D}_{6}\right): \delta 139.4,138.9$, $137.5,137.4,128.7,128.2,127.94,127.91,127.7,80.6,80.5,79.5$, 74.7, 72.0, 68.2, 68.1, 41.6. ${ }^{31} \mathrm{P}$ NMR $\left(\mathrm{C}_{6} \mathrm{D}_{6}\right): \delta$ 23.9. HRMS (ESI) calcd. for $\mathrm{C}_{62} \mathrm{H}_{67} \mathrm{~N}_{2} \mathrm{O}_{10} \mathrm{P}_{2}(\mathrm{M}+\mathrm{H})^{+}:$1061.4271, found: 1061.4294.

1,6-Dideoxy-1,6-dimethansulfonamide-2,3,4,5-tetra-O-benzyl Mannitol (10). Compound 8 (117 mg, $0.20 \mathrm{mmol}$ ) was dissolved in dry toluene $(4 \mathrm{~mL})$ and $\mathrm{PPh}_{3}$ on polystyrene (280 mg, $3.1 \mathrm{mmol} / \mathrm{g}, 0.87 \mathrm{mmol}$ ) was added and the mixture was stirred at $60^{\circ} \mathrm{C}$ for $18 \mathrm{~h}$. The mixture was allowed to cool and mesyl chloride $(0.10 \mathrm{~mL}, 1.29 \mathrm{mmol})$ was added. The mixture was stirred at r.t. under $\mathrm{N}_{2}$ for $90 \mathrm{~min}$ and then $\mathrm{Na}_{2} \mathrm{CO}_{3}(3 \mathrm{~mL}$, sat. aq.) was added. This mixture was stirred at r.t. for an additional $18 \mathrm{~h}$ before the solid support was filtered and washed with EtOAc. The organic phase was washed twice with $\mathrm{H}_{2} \mathrm{O}$ and the aqueous phase was extracted once with EtOAc. The combined organic phase was dried $\left(\mathrm{MgSO}_{4}\right)$ and concentrated. The residue was purified by chromatography (Biotage Isolera One, SNAP $25 \mathrm{~g}$, EtOAc $5-95 \%$ in heptane) to give $\mathbf{1 0}(774 \mathrm{mg}, 60 \%)$ as a clear oil. $[\alpha]_{\mathrm{D}}{ }^{23}+26\left(\mathrm{c} 0.9, \mathrm{C}_{6} \mathrm{H}_{6}\right),{ }^{1} \mathrm{H}$ NMR $\left(\mathrm{C}_{6} \mathrm{D}_{6}\right): \delta 7.41-7.43(\mathrm{~m}$, $4 \mathrm{H}, \mathrm{ArH}), 7.27-7.29(\mathrm{~m}, 4 \mathrm{H}, \mathrm{ArH}) 7.15-7.22(\mathrm{~m}, 8 \mathrm{H}, \mathrm{ArH})$, 7.05-7.12 (m, 4H, ArH), 4.80, $4.71(\mathrm{ABq}, 2 \mathrm{H}$ each, $J 11.3 \mathrm{~Hz}$, $\left.\mathrm{PhCH}_{2}\right), 4.60(\mathrm{t}, 2 \mathrm{H}, \mathrm{J} 6.2 \mathrm{~Hz}, \mathrm{NH}), 4.42,4.38(\mathrm{ABq}, 2 \mathrm{H}$ each, $\left.J 11.6 \mathrm{~Hz}, \mathrm{PhCH}_{2}\right), 3.92-3.93(\mathrm{~m}, 2 \mathrm{H}, \mathrm{H}-3, \mathrm{H}-4), 3.74-3.79$ (m, 2H, H-2, H-5), 3.26-3.39 (m, 4H, H-1, H-1', H-6, H-6' $)$, $2.26\left(\mathrm{~s}, 6 \mathrm{H}, \mathrm{SCH}_{3}\right) .{ }^{13} \mathrm{C} \mathrm{NMR}\left(\mathrm{C}_{6} \mathrm{D}_{6}\right): \delta 138.9,138.4,128.9$, $128.8,128.6,128.4,79.9,79.5,74.8,72.4,43.2$, 39.6. HRMS (ESI) calcd. for $\mathrm{C}_{36} \mathrm{H}_{45} \mathrm{~N}_{2} \mathrm{O}_{8} \mathrm{~S}_{2}(\mathrm{M}+\mathrm{H})^{+}$: 697.2617, found: 697.2624 .

2.2. Microbiology. E. coli $\mathrm{DH} 5 \alpha$ and Pseudomonas putida were precultured overnight in shake flasks containing lysogeny broth (LB) media $(10 \mathrm{~g} / \mathrm{L}$ Bacto tryptone, $5 \mathrm{~g} / \mathrm{L}$ Bacto yeast extract, and $10 \mathrm{~g} / \mathrm{L} \mathrm{NaCl}, \mathrm{pH} 7.0$ ) in an orbital shake incubator set to $180 \mathrm{rpm}$ and $37^{\circ} \mathrm{C}$ for E. coli or $30^{\circ} \mathrm{C}$ 


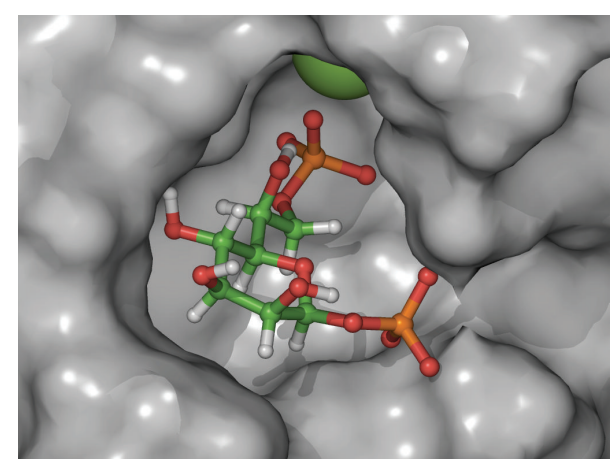

(a)

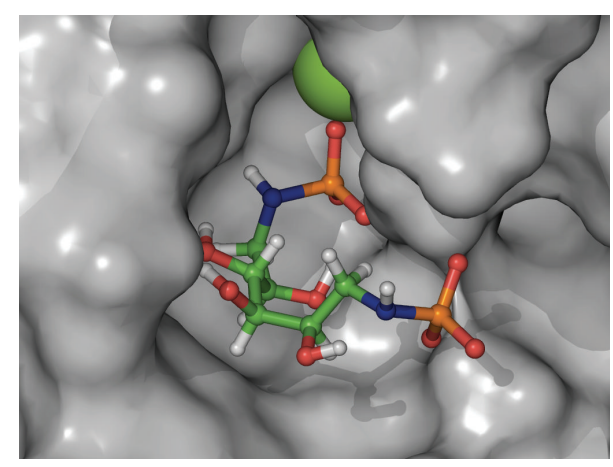

(b)

Figure 3: (a) D-Glycero- $\beta$-D-manno-heptose 1,7-bisphosphate (1) in the binding pocket of GmhB according to the crystal structure from [23]. (b) Molecular dynamic snapshot of 1,6-dideoxy-1,6-diphosphoramidate mannitol (3) in the binding pocket of GmhB.

for P. putida. The bacteria were transferred to an LB-agar plate and incubated at r.t. for $30 \mathrm{~min}$. Compounds 3, 4 and Novobiocin were dissolved in sterile water to a concentration of $10 \mathrm{mg} / \mathrm{mL}$ and transferred to blank discs (Oxoid) according to Table 1. Polymyxin B, 300 units (Oxoid CT0044), and Tetracycline $30 \mathrm{mg}$ (Oxoid CT0054) disc were purchased from Oxoid. The discs were allowed to dry for $5 \mathrm{~min}$ before they were transferred to the LB-agar plate and incubated at r.t. for $1 \mathrm{~h}$ followed by incubation overnight at $37^{\circ} \mathrm{C}$ for $\mathrm{E}$. coli and $30^{\circ} \mathrm{C}$ for $P$. putida. All experiments were run in duplicate.

\section{Results and Discussion}

Molecular dynamics simulations of the two proposed structures were performed on a model based on the X-ray diffraction data of GmhB enzyme from E. coli, with its natural substrate (PDB 3L8G) [23]. The model was prepared using the Schrödinger 2012 software suite by application of the protein preparation tool, followed by energy optimization utilizing the OPLS-2005 forcefield and the GB/SA solvation method for water. For each of the new ligands, a MCMM conformational search utilizing the OPLS-2005 forcefield and the GB/SA solvation method for water was performed. The low energy conformer most similar to the natural ligand was placed on the protein by superimposition, followed by a 2.4 ns molecular dynamics simulation of an orthorhombic box with $10 \AA$ buffer of water molecules, using the default settings of Desmond 2012 [24, 25]. The dimethylsulfonamide 4 did not retain in the binding pocket, perhaps due to the poor interaction with the magnesium ion, and was not a potential inhibitor according to the docking study. The phosphoramidate 3 on the other hand retained in the binding pocket; this makes it an interesting compound to evaluate in a biological assay. The natural substrate $\mathbf{1}$, which also retained in the binding pocket, and a snapshot from the molecular dynamics of 3 are displayed in Figure 3 [26]. Despite the poor interactions of $\mathbf{4}$ in the binding pocket we decided to synthesize and evaluate both analogs in an effort to better understand the system.

Mannitol (5) was selectively ditritylated in positions 1 and 6 using trityl chloride to give 1,6-di-O-trityl mannitol
TABLE 1: Substances tested in duplicate on E. coli and P. putida.

\begin{tabular}{lccc}
\hline Entry & Substance & Amount & Inhibited cell growth \\
\hline 1 & 3 & $100 \mathrm{mg}$ & No \\
2 & $\mathbf{3}+$ Novobiocin & $100 \mathrm{mg}+50 \mathrm{mg}$ & No \\
3 & $\mathbf{3}+$ Novobiocin & $50 \mathrm{mg}+50 \mathrm{mg}$ & No \\
4 & $\mathbf{4}$ & $100 \mathrm{mg}$ & No \\
5 & $\mathbf{4}+$ Novobiocin & $100 \mathrm{mg}+50 \mathrm{mg}$ & No \\
6 & $\mathbf{4}+$ Novobiocin & $50 \mathrm{mg}+50 \mathrm{mg}$ & No \\
7 & Novobiocin & $50 \mathrm{mg}$ & No \\
8 & Polymyxin $\mathrm{B}^{\mathrm{a}}$ & $300 \mathrm{units}$ & Yes \\
9 & Tetracycline $^{\mathrm{a}}$ & $30 \mathrm{mg}$ & Yes \\
10 & $\mathrm{H}_{2} \mathrm{O}$ & $10 \mathrm{mg}$ & No \\
\hline
\end{tabular}

${ }^{\mathrm{a}}$ Discs pretreated with antibiotic from Oxoid.

(6) (Scheme 1) in 76\% yield. The tritylated product 6 was then benzylated followed by detritylation using TFA to get 2,3,4,5-tetra-O-benzyl mannitol (7) in 76\% according to a previously described method [19]. Compound 7 was tosylated with 4-toluenesulfonyl chloride followed by installation of an azide to give 1,6-azido-1,6-dideoxy-2,3,4,5-tetra-Obenzyl mannitol (8) in $60 \%$ yield over two steps. The azide 8 reacted with tribenzyl phosphite in a Staudinger type reaction overnight to yield 1,6-dideoxy-1,6-di-(di-benzylphosphoramidate)-2,3,4,5-tetra-O-benzyl mannitol (9) in $61 \%$ yield $[22,27]$.

The formation of tribenzyl phosphite from phosphorous chloride and benzyl alcohol was troublesome and very sensitive to moisture and air. The reagents had to be freshly distilled prior to the reaction and filtered, to remove triethylammonium chloride, under a nitrogen atmosphere to eliminate the formation of tribenzyl phosphate. Compound 9 was then hydrogenolysed in ethyl acetate/ethanol/water $(3: 5: 2)$ in the presence of $\mathrm{Pd} / \mathrm{C}$ to give 1,6 -dideoxy-1,6diphosphoramidate mannitol (3) in 89\% yield [27].

To synthesize the dimethylsulfonamide analog, compound $\mathbf{8}$ was treated under Staudinger conditions with triphenylphosphine on solid support for $18 \mathrm{~h}$ at $60^{\circ} \mathrm{C}$ followed by addition of methanesulfonyl chloride to form 1,6-dideoxy1,6-dimethansulfonamide-2,3,4,5-tetra-O-benzyl mannitol 

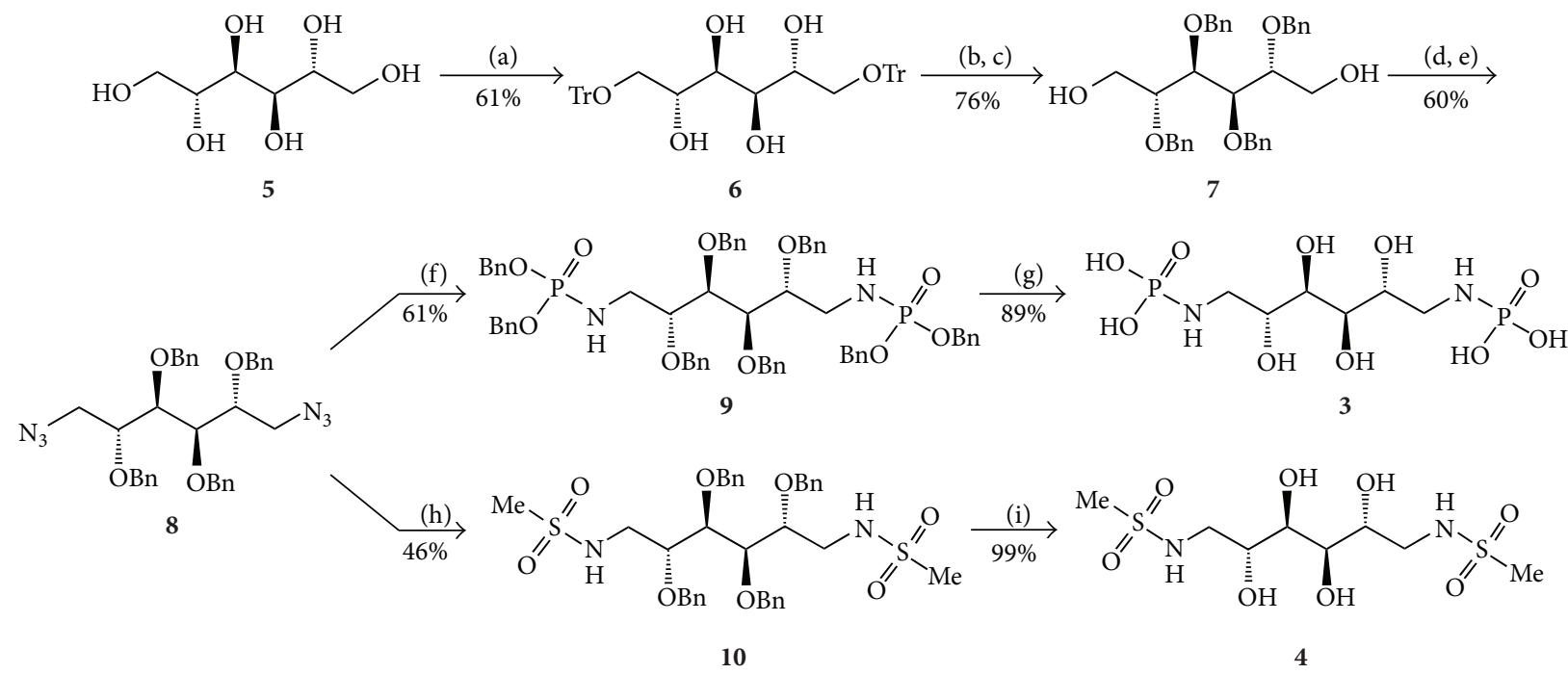

Scheme 1: Reagents and conditions: (a) $\mathrm{Ph}_{3} \mathrm{CCl}, \mathrm{AgNO}_{3}$, pyridine, r.t.; (b) $\mathrm{BnBr}$, NaH, THF, r.t.; (c) TFA, n- $\mathrm{BuOH} \mathrm{CH}_{2} \mathrm{Cl}{ }_{2}$, r.t.; (d) TsCl, pyridine, r.t.; (e) $\mathrm{NaN}_{3}$, DMSO, $100-150^{\circ} \mathrm{C}$; (f) $\mathrm{P}(\mathrm{OBn})_{3}$, toluene, r.t. to $90^{\circ} \mathrm{C}$; (g) $\mathrm{Pd} / \mathrm{C}, \mathrm{H}_{2}$, EtOAc/EtOH/ $\mathrm{H}_{2} \mathrm{O}$, r.t.; (h) $\mathrm{MsCl}$, $\mathrm{PS}-\mathrm{PPh} 3$, toluene, r.t. to $60^{\circ} \mathrm{C}$; and (i) $\mathrm{Pd} / \mathrm{C}, \mathrm{H}_{2}$, EtOAc/EtOH/ $\mathrm{H}_{2} \mathrm{O}$ r.t.

(10) in 46\% yield (Scheme 1) [27]. Compound 10 was then hydrogenolysed under the same conditions as $\mathbf{9}$, but more $\mathrm{Pd} / \mathrm{C}$ had to be added since sulfur residue poisoned the catalyst. This gave 1,6-dideoxy-1,6-dimethansulfonamide mannitol (4) in 99\% yield.

To evaluate the biological properties of these compounds, the cell growth was monitored for two different Gramnegative bacteria, E. coli and P. putida, in the Kirby-Bauer antibiotic susceptibility test with and without addition of Novobiocin. Complete loss of access to L,D-Hep would result in bacterial cells with a truncated LPS. The impairment would result in hypersensitivity towards a range of compounds including the antibiotic Novobiocin that is usually not effective against Gram-negative bacteria [11]. Discs were impregnated with 3, 4 or a mixture of Novobiocin and 3 or 4 according to Table 1 and placed on a LB-agar plate that had been streaked with the bacteria. Positive controls (Tetracycline and Polymyxin B) and water as a negative control were also added and the plates were incubated overnight at $37^{\circ} \mathrm{C}$ for E. coli and $30^{\circ} \mathrm{C}$ for P. putida.

Only Tetracycline and Polymyxin B (Table 1, entries 89) showed inhibition of cell growth for both E. coli and P. putida and no inhibition was seen for 3, 4, Novobiocin, or Novobiocin in combination with 3 or $\mathbf{4}$ (Table 1, entries 1-7). The absence of activity in the Kirby-Bauer antibiotic susceptibility test could be contingent on several different things; for example, the compounds might not be competitive inhibitors for the enzyme, or other mechanisms such as uptake or efflux may be responsible for the lack of activity.

\section{Conclusion}

To summarize, we have designed, synthesized, and evaluated two new mannitol-based compounds aimed at inhibiting the enzyme GmhB in the L,D-Hep biosynthesis in Gramnegative bacteria. All levels of the $\mathrm{L}, \mathrm{D}-\mathrm{Hep}$ biosynthesis are promising and underexplored targets for new antibiotics and $\mathrm{GmhB}$ is an attractive enzyme to target. A deletion of the gene that codes for $\mathrm{GmhB}$ in $E$. coli does not give a completely heptoseless LPS, indicating that there are other enzymes that will partly compensate for this protein [13]. However, in other bacteria, the protein $\mathrm{GmhB}$ is crucial [28] for the production of L,D-Hep, something that can be utilized in the design of more specific antibiotic agents. The compounds were evaluated in silico and in the KirbyBauer antibiotic susceptibility test on two different Gramnegative bacteria. While 1,6-dideoxy-1,6-diphosphoramidate mannitol (3) showed encouraging results in silico, neither of them showed any activity in the Kirby-Bauer test. However, the encouraging result in silico merits further investigation into mannitol-based inhibitors for $\mathrm{GmhB}$, something that is currently ongoing in our laboratory.

\section{Disclosure}

The author's current affiliation is Red Glead Discovery AB, Medicon Village, 22381 Lund, Sweden.

\section{Conflict of Interests}

The author declares that there is no conflict of interests regarding the publication of this paper.

\section{Acknowledgments}

The author thanks Anders Sundin for computational chemistry calculations and Magnus Carlquist for help with microbiological evaluation. This work was supported by the foundation Längmanska Kulturfonden and Magnus Bergvall's Foundation. 


\section{References}

[1] D. J. Payne, "Desperately seeking new antibiotics," Science, vol. 321, no. 5896, pp. 1644-1645, 2008.

[2] B. Walker, S. Barrett, S. Polasky et al., "Looming global-scale failures and missing institutions," Science, vol. 325, no. 5946, pp. 1345-1346, 2009.

[3] B. Spellberg, M. Blaser, R. J. Guidos et al., "Combating antimicrobial resistance: policy recommendations to save lives," Clinical Infectious Diseases, vol. 52, no. 5, pp. S397-S428, 2011.

[4] H. S. Gold and R. C. Moellering Jr., "Antimicrobial-drug resistance," The New England Journal of Medicine, vol. 335, no. 19, pp. 1445-1453, 1996.

[5] M. A. Fischbach and C. T. Walsh, "Antibiotics for emerging pathogens," Science, vol. 325, no. 5944, pp. 1089-1093, 2009.

[6] G. Taubes, "The bacteria fight back," Science, vol. 321, no. 5887, pp. 356-361, 2008.

[7] J. A. Yethon and C. Whitfield, "Lipopolysaccharide as a target for the development of novel therapeutics in Gram-negative bacteria," Current Drug Targets: Infectious Disorders, vol. 1, no. 2, pp. 91-106, 2001

[8] H. Nikaido, "Prevention of drug access to bacterial targets: permeability barriers and active efflux," Science, vol. 264, no. 5157, pp. 382-388, 1994.

[9] S. Gronow and H. Brade, "Lipopolysaccharide biosynthesis: which steps do bacteria need to survive?" Journal of Endotoxin Research, vol. 7, no. 1, pp. 3-23, 2001.

[10] C. R. H. Raetz and C. Whitfield, "Lipopolysaccharide endotoxins," Annual Review of Biochemistry, vol. 71, pp. 635-700, 2002.

[11] W. G. Coleman Jr. and L. Leive, "Two mutations which affect the barrier function of the Escherichia coli K-12 outer membrane," Journal of Bacteriology, vol. 139, no. 3, pp. 899-910, 1979.

[12] M. N. Alekshun and S. B. Levy, "Targeting virulence to prevent infection: to kill or not to kill?” Drug Discovery Today: Therapeutic Strategies, vol. 1, no. 4, pp. 483-489, 2004.

[13] B. Kneidinger, C. Marolda, M. Graninger et al., "Biosynthesis pathway of ADP-L-glycero- $\beta$-D-manno-heptose in Escherichia coli," Journal of Bacteriology, vol. 184, no. 2, pp. 363-369, 2002.

[14] M. A. Valvano, P. Messner, and P. Kosma, "Novel pathways for biosynthesis of nucleotide-activated glycero-manno-heptose precursors of bacterial glycoproteins and cell surface polysaccharides," Microbiology, vol. 148, no. 7, pp. 1979-1989, 2002.

[15] E. Kuznetsova, M. Proudfoot, C. F. Gonzalez et al., "Genomewide analysis of substrate specificities of the Escherichia coli haloacid dehalogenase-like phosphatase family," The Journal of Biological Chemistry, vol. 281, no. 47, pp. 36149-36161, 2006.

[16] A. Ginsburg and A. H. Mehler, "Specific anion binding to fructose diphosphate aldolase from rabbit muscle," Biochemistry, vol. 5, no. 8, pp. 2623-2634, 1966.

[17] J. M. Ingram, "The combining sites of yeast fructose diphosphate aldolase," Biochemical and Biophysical Research Communications, vol. 38, no. 4, pp. 624-630, 1970.

[18] C. J. Marcus, "Inhibition of bovine hepatic fructose-1,6diphosphatase by substrate analogs," Journal of Biological Chemistry, vol. 251, no. 10, pp. 2963-2966, 1976.

[19] C.-G. Mabiala-Bassiloua, M. Zwolinska, H. Therisod, J. Sygusch, and M. Therisod, "Separate synthesis and evaluation of glucitol bis-phosphate and mannitol bis-phosphate, as competitive inhibitors of fructose bis-phosphate aldolases," Bioorganic and Medicinal Chemistry Letters, vol. 18, no. 5, pp. 1735-1737, 2008.
[20] M. Metzke and Z. Guan, "Structure-property studies on carbohydrate-derived polymers for use as protein-resistant biomaterials," Biomacromolecules, vol. 9, no. 1, pp. 208-215, 2008.

[21] M.-C. Matos and P. V. Murphy, "Synthesis of macrolidesaccharide hybrids by ring-closing metathesis of precursors derived from glycitols and benzoic acids," Journal of Organic Chemistry, vol. 72, no. 5, pp. 1803-1806, 2007.

[22] U. Wong and R. J. Cox, "The chemical mechanism of D-1deoxyxylulose-5-phosphate reductoisomerase from Escherichia coli," Angewandte Chemie-International Edition, vol. 46, no. 26, pp. 4926-4929, 2007.

[23] H. H. Nguyen, L. Wang, H. Huang, E. Peisach, D. DunawayMariano, and K. N. Allen, "Structural determinants of substrate recognition in the HAD superfamily member D-glycero-Dmanno-heptose-1,7-bisphosphate phosphatase (GmhB)," Biochemistry, vol. 49, no. 6, pp. 1082-1092, 2010.

[24] Desmond Molecular Dynamics System, Version 3.1, D. E. Shaw Research, New York, NY, USA, 2012.

[25] Maestro-Desmond Interoperability Tools, Version 3.1, Schrödinger, New York, NY, USA, 2012.

[26] The PyMOL Molecular Graphics System, Version 1.5.0.4, Schrödinger, LLC, New York, NY, USA, 2013.

[27] M. Durka, A. Tikad, R. Périon et al., "Systematic synthesis of inhibitors of the two first enzymes of the bacterial heptose biosynthetic pathway: towards antivirulence molecules targeting lipopolysaccharide biosynthesis," Chemistry - A European Journal, vol. 17, no. 40, pp. 11305-11313, 2011.

[28] G. C. Shih, C. M. Kahler, R. W. Carlson, M. M. Rahman, and D. S. Stephens, " $g m h X$, a novel gene required for the incorporation of L-glycero-D-manno-heptose into lipooligosaccharide in Neisseria meningitidis," Microbiology, vol. 147, part 8, pp. 23672377, 2001. 

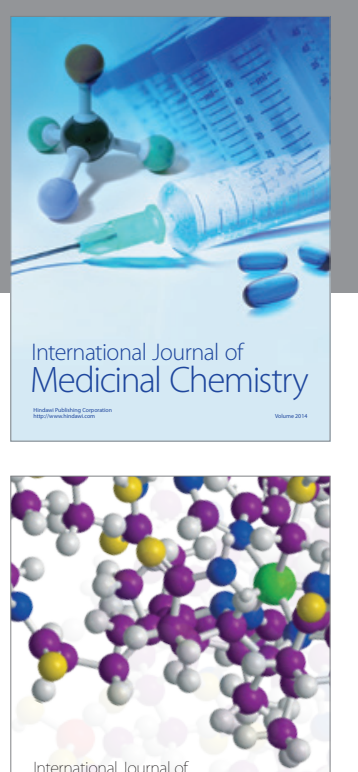

Carbohydrate Chemistry

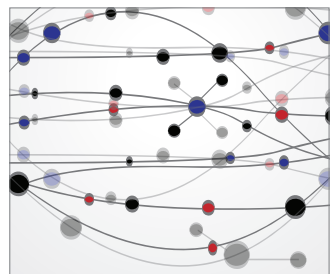

The Scientific World Journal
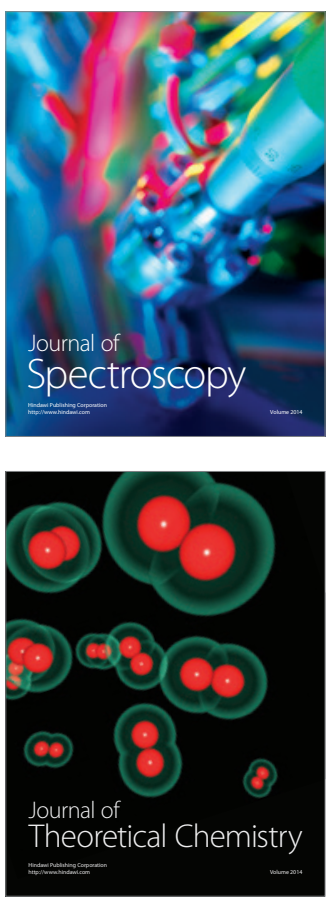
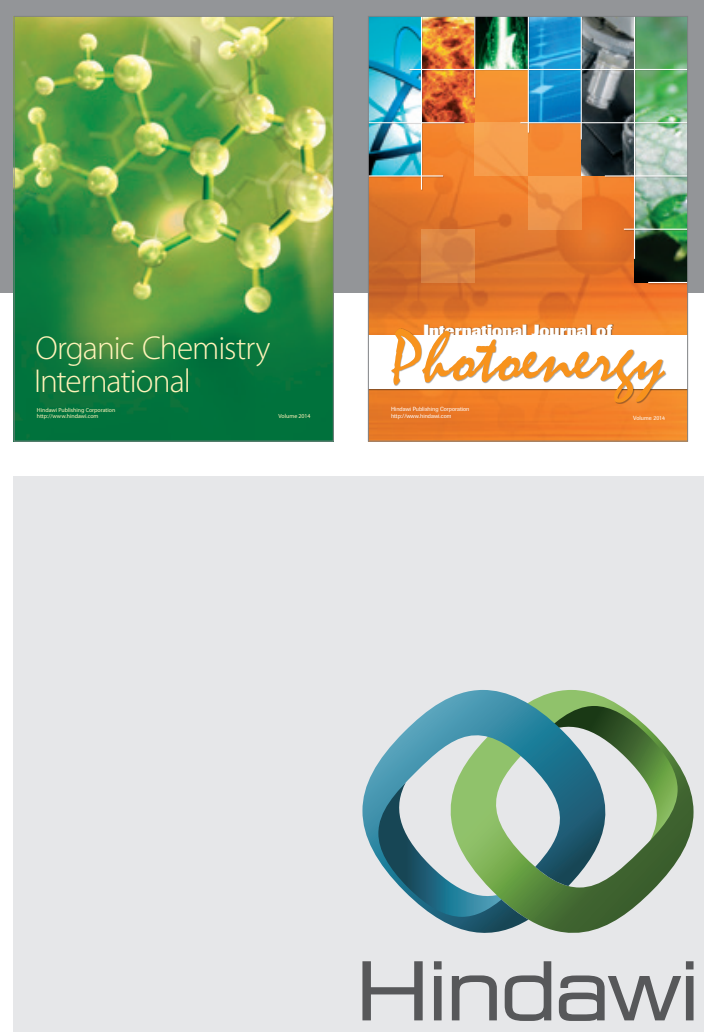

Submit your manuscripts at

http://www.hindawi.com

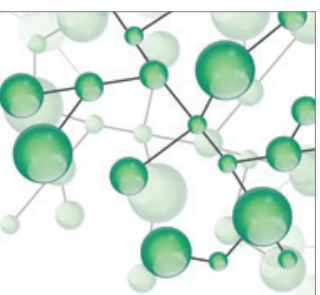

International Journal of

Inorganic Chemistry

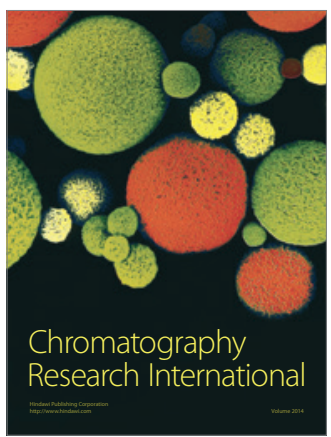

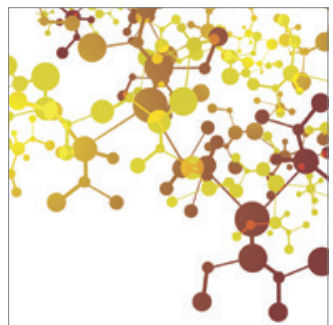

Applied Chemistry
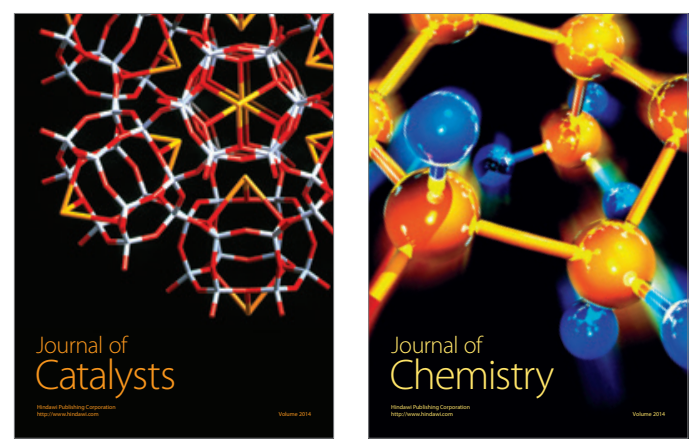
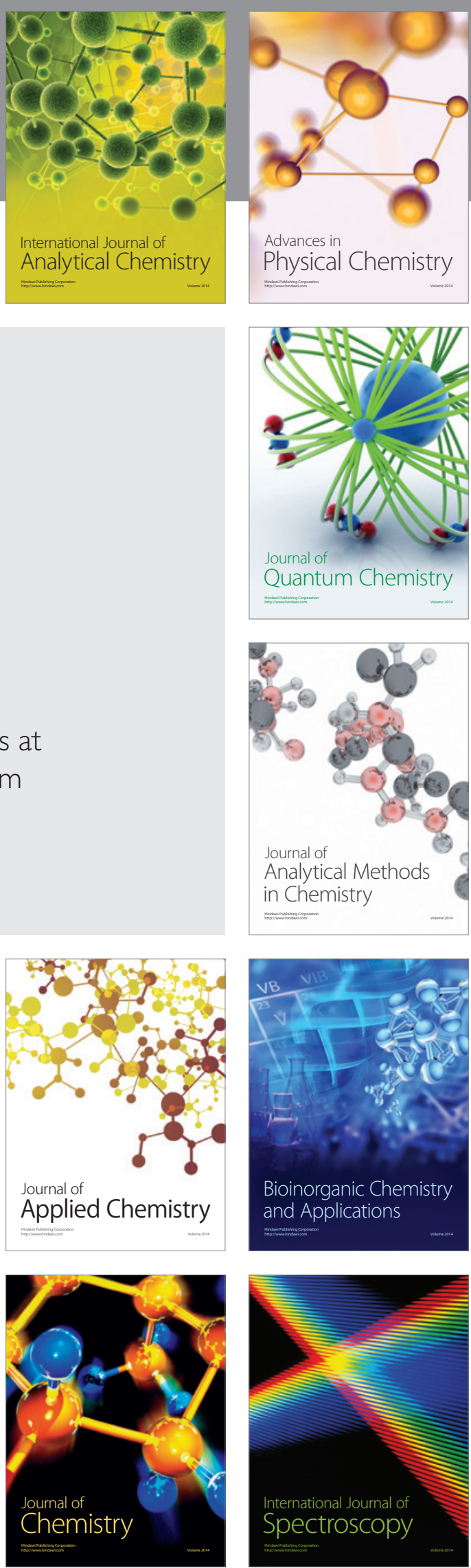